Although in Manchester and Salford the percentage of cases of squint diagnosed within a year of its onset was about $80-90 \%$ in children who began to squint between the ages of 2 and 6 , it was considerably lower among those who began to squint at an age of under 1 year, indeed only about $50 \%$. This is no doubt due to the old-fashioned idea that very young infants are too young for diagnosis and treatment. No infant is too young for examination and diagnosis nor for treatment by occlusion (if indicated). In some cases, for instance those of freely alternating squint, the early management may, in the absence of relevant errors of refraction, merely consist in periodic and careful observation. Moreover, the clinician must always bear in mind that a squint may be the outward sign of some serious ocular disease or may be paretic in nature and due to some underlying neurological disorder necessitating further investigation.

It is not always realized that a constant unilateral convergent squint which might otherwise end in a relatively blind eye may, as a result of timely occlusion, become converted into one of freely alternating convergent squint. This will ensure that both eyes keep good vision, and subsequently if the squint is controlled by correction of the refractive error or by surgery and orthoptic treatment or both thr child may attain binocular single vision or, failing that, some useful form of binocular association. The development and preservation of good vision in each eye of a young child is a duty which every ophthalmologist must accept, but in order to discharge this duty he must rely on the early referral of all cases of squint by general practitioners, paediatricians, doctors in infant welfare clinics, health visitors, and others, but perhaps above all on its early recognition by parents and relatives, especially when there is a family history of squint. Delay in diagnosis and treatment is dangerous.

\section{Fall-out and Strontium}

After the explosion of the first hydrogen bomb in 1954 radioactive contamination of the environment and of human tissues reached measurable levels in many parts of the world. The long-term significance of fall-out is linked with deposition of strontium-90, a radioactive isotope with a halflife of 28 years. Because of its chemical affinity with calcium, this material is deposited in the skeleton, where it may be detected by chemical treatment and radioactive assay of bone samples obtained post mortem.

Work of this sort began in Great Britain in $1955^{1}$ and is now conducted by two groups (one at the Capenhurst laboratories of the United Kingdom Atomic Energy Authority and one in Glasgow), who analyse more than 400 bone samples a year. The concentration of strontium- 90 in bone is greater in children than in adults. The level of contamination rose to a peak in 1959 and declined slowly for three years before rising to another maximum in 1964 and 1965. The latest report ${ }^{2}$ from the Medical Research Council, covering the first half of 1966 , shows that levels of strontium90 in bone continue to decline slowly, though remaining higher than at any time before 1964 .

\footnotetext{
1 Bryant, F. J., Chamberlain, A. C., Morgan, A., and Spicer, G. S., Radiostrontium in Soil, Grass, Milk and Bone in the United Kingdom, 1956, Results (A.E.R.E. HP/R 2533). 1957. H.M.S.O. ${ }^{*}$ Medical Research Council Monitoring Report No. 14, Assay of 1966, part 1. 1967. H.M.S.O.
}

Arrangements for the analysis of human bone samples in the United Kingdom have been altered in a small but significant way. Until now the femur has been used in the British programme, but vertebrae have been analysed in most other countries. The difference is not important for infants, children, and adolescents, for whom little variation has been found in strontium-90 levels among the bones of the skeleton. In adults, however, the concentration of strontium-90 in vertebral bone is two to three times greater than in the femur. It has now been decided that the United Kingdom Atomic Energy Authority team (who receive an appreciable number of samples from adult subjects as well as from infants and children) will use vertebrae for analysis. The Glasgow group, whose work is confined mainly to study of samples from subjects under 5 years of age, will continue to analyse femora.

For the present, levels of strontium-90 in human bone do not give cause for serious anxiety in regard to radiation hazards, but valuable information is beginning to emerge from the study of the long series of results now available and from comparisons with other countries, where diet and weather conditions lead to differences in uptake of radioactive fall-out.

\section{Coin - operated Vending Machines}

The coin-operated vending machine answers a demand for quick meals and drinks at any hour of the day or night. Labour is minimal, being required only for maintenance and supplies. The machines are filled by the occupant of the land or premises on which they stand or by the company operating them. They may be either hired or purchased. If hired their maintenance is the responsibility either of the company loaning the machines or of those hiring them. Vending machines may be found in factories, hospitals, offices, and air, rail, or sea terminals, garages, sports grounds, exhibition halls, and also in streets and arcades of towns and cities. The food sold ranges from hot meals and sandwich or pie snacks to hot or cold drinks of many varieties.

The food is stored in an enclosed system, so that a simple cleaning process is essential to avoid the accumulation of stale food, particularly in powdered form, or liquid in parts of the machine invisible to the public eye. Many of the cold foods are perishable-for example, meat sandwiches, pies, and sausage rolls. Thus the temperature of storage is important and also the length of time the foods are held in the machine. The Food Hygiene Code of Practice No. 7, 1 of which $\mathbf{M}$. Parry $^{2}$ has discussed the background, recommends a temperature of storage in accordance with the Food Hygiene Regulations ${ }^{3}$ - that is, below $10^{\circ}$ C. $\left(50^{\circ}\right.$ F.) or above $62^{\circ} \mathrm{C}$. $\left(145^{\circ} \mathrm{F}\right.$.) - though these regulations apply only to food for immediate consumption in catering establishments. The Code of Practice gives no recommended time of storage for perishable products in vending machines, which in fact are acting as domestic refrigerators and should be operated at

\footnotetext{
Hygiene in the Operation of Coin-operated Food Vending Machines, Food Hygiene Code of Practice No. 7, 1967. H.M.S.O. Food Hygiene Code of Practice No. 7, 1967.

2 Parry, M., Publ. Hlth Inspect., 1967, 75, 369. Statutory Instruments (1960), The Food
tions, 1960, Cmnd. 1601. H.M.S.O.

4 Hughes, H. L., Munic. Engng. Lond., 1967, 144, 926.

Skinner, W. E. D., Roy. Soc. Hlth f., 1967, 87, 19.

- Bailey, C. A., Publ. Hlth Inspect., 1967, 75, 306.

7 Gibson, H. G., ibid., 1966, 75, 121.
} 